Article

\title{
Leather Thermal and Environmental Parameters in Fire Conditions
}

\author{
Marzena Półka iD \\ The Main School of Fire Service, 01-629 Warsaw, Poland; mpolka@sgsp.edu.pl \\ Received: 8 October 2019; Accepted: 14 November 2019; Published: 16 November 2019
}

\begin{abstract}
The thermal decomposition of leather-product combustion produces some inflammable and harmful compounds after tanning, fat liquoring, dyeing, and finishing processes. These organic compounds are ignited and release a lot of toxic gases and smoke in fire conditions, polluting the atmosphere air. On this account, it is very important to know leather safety performance for fire prevention. The flammability and thermal stability of types of leather at thermal expositions stimulating fire conditions were analyzed. Five types of leather were used in experimental testing, four of animal origin and an artificial one. Results showed that, in the analyzed heat exposure, the highest average heat-release rate $\left(174 \mathrm{~kW} / \mathrm{m}^{2}\right)$ and smoke generation, and the lowest temperature of the beginning of thermal decomposition, were recorded for the artificial leather. Leather flammability essentially depends on the type of applied energy stimulus, as well as hide composition and origin. A possible cause for differences in the obtained results of the leather analyses is the percentage of certain leather components and their chemical composition.
\end{abstract}

Keywords: air pollution; heat and smoke release; leather fire safety; toxic-gas emission

\section{Introduction}

Given its good air permeability and wearing abrasion, leather finds diverse applications in different industrial sectors. It may be used for the production of furniture, clothing, haberdashery, or simple home decorations. In tanning, which is one of the main unit leather-processing processes, diverse methods have been adopted to make leather resistant to decay or to have it acquire appropriate features for its intended functions. At this stage, the producer primarily focuses on the product's esthetical values, its appropriate appearance, required coloring, and the acquisition of the desired properties. Taking into account its structure and composition, leather offers natural and relatively high resistance to fire, but it is generally a flammable material that may burn both without and with a flame [1,2]. Inappropriate storage of leather, lack of proper care with regards to fire protection, or simple recklessness may start a fire, and heat and smoke released from leather unquestionably affect fire dynamics inside building structures. Hence, it is important to know leather's flammable properties to ensure better fire safety. Fire affects the surroundings of a building and changes the surroundings [3-5] in the visibility range inside a premise, and the thermal conditions and chemical composition of the atmosphere (toxicity). High temperature, intensity of thermal radiation, and critical states related to limiting the visibility range and concentration of toxic products are associated with the heat and smoke release rate, and the thermal stability of materials. Awareness of potential hazards that may arise during leather combustion allows reducing the risk of its occurrence. For this reason, this topic has been selected to determine essential parameters of flammability and thermal stability of various leather types.

Products of thermal decomposition and combustion released from leather may contain easily flammable and harmful organic substances, such as, among others, compounds left after the fat-liquefaction, dyeing, and finishing processes of those materials [1,6]. In [2], the authors presented 
the impact of individual leather-processing operations (e.g., tanning, oiling) and of additives used in them, such as tannins and oiling, retanning agents and those that reduce flammability, on the quality of the produced materials. Subsequent studies $[7,8]$ comprised analyses pertaining to the impact exerted by tanning, including the application of diverse tannins (chromic tannin, tannin based on glutaric aldehyde, and vegetal tanning agents) on leather flammability. In addition, dependence has been detected between leather density and flammability. It has been proven that the lowest flammability was found in leather with vegetal tanning, which is also characterized by the largest density, followed by chromic-tanning leather, and finally, leather tanned with the use of aldehyde tannin. Analysis was carried out [5] on the impact exerted by various film-forming agents based on polyurethane, polyacrylate, nitrocellulose, and protein on the leather-finishing process. Studies have shown that the introduction of pigment to the film-forming material clearly increases leather flammability, but an extensive amount of a finishing coat causes reduced resistance to combustion. Given the flammability of leather, an important element in leather processing is its oiling. In the majority of cases, leather is oiled with the emulsion method. The capability of forming the water emulsion of fats is obtained, among others, by sulphating and sulphite processing. The application of sulphating oils causes considerable leather ignitability as compared to sulphite oils [9]. Other studies have shown that leather materials containing an expanding protection agent may allow the significant lowering of its flammable properties [9-16]. First, a novel intumescent flame retardant (IFR) was prepared as an intermediate compound of pentaerythritol, phosphorus oxychloride, melamine, and tetrakis hydroxymethyl phosphonium chloride; afterwards, a novel nanocomposite was successfully produced and tested from IFR and montmorillonite (OMMT), modified by cetyltrimethyl ammonium bromide (CTAB) and collagen [11]. The novel OMMT and IFR nanocomposite was applied to leather in the tanning process. The intercalated or stripping type of nanocomposite could be obtained according to certain reaction conditions. Limited oxygen index research and cone calorimeter results [11] showed that the nanocomposite had a good charring effect, could effectively improve leather nonflammability, and has good flame-resistance properties. Research [12] tested leather combustion in different atmospheres with the aid of thermogravimetric analysis. Regardless of individual material or blend, the replacement of $\mathrm{N}_{2}$ by only $\mathrm{CO}_{2}$ resulted in smaller weight-loss rates, a change in reactions occurring above $600{ }^{\circ} \mathrm{C}$, and a worse burnout; the oxygen-enriched combustion technology could, to some extent, alleviate the inhibitory effects. Analyses were carried out for the same individual material or blend of the apparent activation energies. The highest value of activation energy was recorded for the adoption of atmosphere that consisted of $80 \% \mathrm{CO}_{2}$ and $20 \% \mathrm{O}_{2}$, and amounted to $150.36 \mathrm{~kJ} / \mathrm{mol}$. In another study [17], analysis was conducted on the impact excreted by the addition of melamine and silica in the retanning process on certain properties, including flammability. Melamine and silica, as a composite based on acrylic resin, were introduced to bovine leather subjected to chromic tanning with the use of an asymmetric selection of samples. In this form, thermal-resistance tests were conducted, along with measurements of flammability resistance. Study results showed that as the amount of used composite material grew, leather mass loss was reduced, which proved the enhancement of thermal resistance. A dominating impact on thermal resistance was exerted by melamine. During the thermal decomposition of leather, the released organic compounds undergo ignition relatively easily from a piloted flame or a heated surface, and release toxic products and smoke [17-19]. Many works are currently carried out using leather waste for various industrial applications, so it is necessary to know what kind of fire hazard they could have [20-24]. The aim of the study was analysis of the influence of the composition and type of tested leather on the heat and smoke release rate, together with thermostability and flammability analysis from a small piloted flame. Inadequate storage, negligence of fire protection, or simple recklessness can lead to the onset of fire and changes in the air atmosphere; in this sense, this article has pioneering and cognitive value.

\section{Materials and Methods}

Five types of leather were used in the experiment testing, 4 of animal origin and 1 artificial, namely, 
(1) grain bovine leather;

(2) goat leather;

(3) artificial leather (leatherette);

(4) pig leather; and

(5) velour bovine leather.

The elementary composition of samples is presented in Table 1. The elemental composition of the tested materials was determined at the Institute of Organic Chemistry of the Polish Academy of Sciences in the Laboratory of Elemental Analysis. The chrome-tanned analyzed leather came from a selected shoe-manufacturing plant from Poland. Goat leather was of the Chevreau type, which means elegant chrome-tanned outer leather. The tested leatherette was polyester, and its composition was reserved by the manufacturer.

Table 1. Sample elementary composition.

\begin{tabular}{ccccc}
\hline \multirow{2}{*}{ Material Name } & \multicolumn{4}{c}{ Elementary Composition } \\
\cline { 2 - 5 } & $\mathbf{\%} \mathbf{C}$ & $\mathbf{\% H}$ & $\mathbf{\% N}$ & $\mathbf{\% S}$ \\
\hline Grain bovine leather & 45.75 & 6.56 & 8.56 & 1.4 \\
Goat leather & 45.94 & 6.07 & 11.75 & 2.11 \\
Artificial leather & 62.62 & 4.07 & 1.68 & no \\
Pig leather & 42.65 & 6.6 & 11.86 & 0.87 \\
Velour bovine leather & 41.49 & 6.25 & 13.09 & 0.86 \\
\hline
\end{tabular}

For the study objective, testing was performed with the use of a cone calorimeter, a TA INSTRUMENTS Q500 thermogravimeter, and a research apparatus for determining the ignition temperature of volatile combustion products.

Cone-calorimeter (CC; Fire Testing Technologies, UK) tests were performed to investigate leather reaction to fire [25]. CC test parameters: sample size was $100 \times 100 \times 2 \mathrm{~mm}$, heat flow was 30 and $50 \mathrm{~kW} / \mathrm{m}^{2}$, and distance from ignition source was $25 \mathrm{~mm}$. The CC test was performed in accordance with ISO 5660. All tested samples were exposed to external heat flux, which simulated the first phase of a fire. Use was made of the 5 leather-type samples at the analyzed thermal-flux density.

Tested samples having a mass of ca. $30 \mathrm{mg}$ were subjected to thermogravimetric analysis with the dynamic method [26]. Measurements were taken within a temperature range of $20-800{ }^{\circ} \mathrm{C}$ at a constant heating rate of $10^{\circ} \mathrm{C} / \mathrm{min}$. Selection of the sample heating rate showed that this was an average heating-rate value of the particular types of material in full-scale fires. The oxidizing atmosphere (air) was produced by preserving a constant air flow of $90 \mathrm{~mL} / \mathrm{min}$ and the flow of a neutral gas (nitrogen) equal to $10 \mathrm{~mL} / \mathrm{min}$. On the basis of our own studies, we estimated the measurement precision: temperature, $1{ }^{\circ} \mathrm{C}$; sample mass, $0.01 \mathrm{mg}$; and heating rate, $1^{\circ} \mathrm{C} / \mathrm{min}$.

Determination of the ignition temperature of leather thermal-decomposition products [27] consisted of the determination of the lowest furnace temperature at which ignition takes place, in $5 \mathrm{~s}$ of gaseous thermal-decomposition products as an effect of the impact of the pilot stimulus, and, namely, of the flame, for $5 \mathrm{~min}$. The testing method comprised placing $1 \mathrm{~g}$ of the dust sample in a thimble (cylindrical container with a cover and an opening for released gaseous and vapor products of thermal decomposition), which was then introduced into one of the provided openings in the furnace block. The temperature of the furnace, working within the range of 150 to $400{ }^{\circ} \mathrm{C}$, was regulated with the use of a control panel pursuant to the standard [27], and was preset at a temperature $10^{\circ} \mathrm{C}$ lower than the anticipated thermal-decomposition temperature of the sample. Once the release of gaseous thermal-decomposition products started from the thimble, a gaseous burner flame no longer than $10 \mathrm{~mm}$ was applied, and product ignition was then commenced. Error of this method equaled to $10^{\circ} \mathrm{C}$. The final result, that is, the mean arithmetic value from 3 measurements of the ignition temperature, did not differ by more than $10^{\circ} \mathrm{C}$. 


\section{Results}

Tables 2 and 3 present the test results of the selected leather types, obtained with the use of a cone calorimeter at an exposure of 30 and $50 \mathrm{~kW} / \mathrm{m}^{2}$. These are the arithmetic means of the value of five measurements, and the maximum deviation from the mean value was up to $10 \%$, depending on the type of sample. Measurement-uncertainty analysis of the heat-release rate for five measurements was made according to ISO 5660:2002; with Student's t-distribution for the use of extended extension $\mathrm{k}=2.8$ for a confidence level of 0.95 , according to the literature [28-30], it was about $10 \%$.

Table 2. Thermal-environmental leather properties at heat-flux density equal to 30 and $50 \mathrm{~kW} / \mathrm{m}^{2}$ in pilot-ignition conditions.

\begin{tabular}{|c|c|c|c|c|}
\hline \multirow[t]{2}{*}{ Leather Type } & $\begin{array}{c}\text { Maximum } \\
\text { Heat-Release Rate } \\
\left(\mathrm{HRR}_{\max } ; \mathrm{kW} / \mathrm{m}^{2}\right)\end{array}$ & $\begin{array}{c}\text { Average } \\
\text { Heat-Release Rate } \\
\left(\mathrm{HRR}_{\mathrm{av}} ; \mathrm{kW} / \mathrm{m}^{2}\right)\end{array}$ & $\begin{array}{c}\text { Maximum } \\
\text { Smoke-Emission } \\
\text { Rate }\left(\mathrm{SPR} ; \mathrm{m}^{2} / \mathrm{s}\right)\end{array}$ & $\begin{array}{l}\text { Mass-Loss Rate } \\
\text { MLR (g/s) }\end{array}$ \\
\hline & \multicolumn{4}{|c|}{ External heat flux-30 kW/m $\mathrm{m}^{2}$} \\
\hline $\begin{array}{c}\text { Grain bovine } \\
\text { leather }\end{array}$ & 218 & 80 & 0.0185 & 0.19 \\
\hline Goat leather & 94 & 24 & 0.022 & 0.1 \\
\hline Artificial leather & 207 & 105 & 0.02955 & 0.205 \\
\hline Pig leather & 96 & 33 & 0.01445 & 0.065 \\
\hline \multirow[t]{2}{*}{$\begin{array}{l}\text { Velour bovine } \\
\text { leather }\end{array}$} & 153 & 75 & 0.0183 & 0.185 \\
\hline & \multicolumn{4}{|c|}{ External heat flux-50 kW/m $\mathrm{m}^{2}$} \\
\hline $\begin{array}{l}\text { Grain bovine } \\
\text { leather }\end{array}$ & 221 & 113 & 0.02225 & 0.22 \\
\hline Goat leather & 121 & 56 & 0.0189 & 0.18 \\
\hline Artificial leather & 285 & 174 & 0.0431 & 0.295 \\
\hline Pig leather & 135 & 61 & 0.01255 & 0.185 \\
\hline $\begin{array}{l}\text { Velour bovine } \\
\text { leather }\end{array}$ & 222 & 110 & 0.03175 & 0.20 \\
\hline
\end{tabular}

Table 3. Thermal-environmental leather parameters and leather physical properties at of 30 and $50 \mathrm{~kW} / \mathrm{m}^{2}$ exposure in pilot-ignition conditions.

\begin{tabular}{|c|c|c|c|c|}
\hline \multirow{2}{*}{ Leather Type } & $\begin{array}{l}\text { Time to Ignition } \\
\text { (s) }\end{array}$ & $\begin{array}{l}\text { Time to HRRmax } \\
\text { (s) }\end{array}$ & $\begin{array}{c}\text { Specified Emission CO } \\
(\mathrm{mg} / \mathrm{g})\end{array}$ & $\begin{array}{c}\text { Specified Emission } \mathrm{CO}_{2} \\
(\mathrm{mg} / \mathrm{g})\end{array}$ \\
\hline & \multicolumn{4}{|c|}{ External heat flux-30 kW/m $\mathrm{m}^{2}$} \\
\hline $\begin{array}{l}\text { Grain bovine } \\
\text { leather }\end{array}$ & 52 & 74 & 2.85 & 21.4 \\
\hline Goat leather & 110 & 121 & 3.04 & 21.25 \\
\hline Artificial leather & 20 & 45 & 3.25 & 24.2 \\
\hline Pig leather & 82 & 107 & 4.52 & 31.21 \\
\hline \multirow[t]{2}{*}{$\begin{array}{l}\text { Velour bovine } \\
\text { leather }\end{array}$} & 64 & 92 & 4.55 & 30.79 \\
\hline & \multicolumn{4}{|c|}{ External heat flux-50 kW/m $\mathrm{m}^{2}$} \\
\hline $\begin{array}{l}\text { Grain bovine } \\
\text { leather }\end{array}$ & 18 & 34 & 2.64 & 21.69 \\
\hline Goat leather & 28 & 39 & 3.38 & 24.82 \\
\hline Artificial leather & 6 & 23 & 2.14 & 21.25 \\
\hline Pig leather & 29 & 52 & 3.13 & 25.45 \\
\hline $\begin{array}{l}\text { Velour bovine } \\
\text { leather }\end{array}$ & 36 & 67 & 2.13 & 18.59 \\
\hline
\end{tabular}


The dependence of heat-release rate on the function of time for the tested samples is shown in Figures 1 and 2, which depict the selected HRR curve from the five determined samples of the tested material; in a representative and averaged way, this only represents the shape of the curve and the intensity of heat release from the samples at a given thermal exposure.

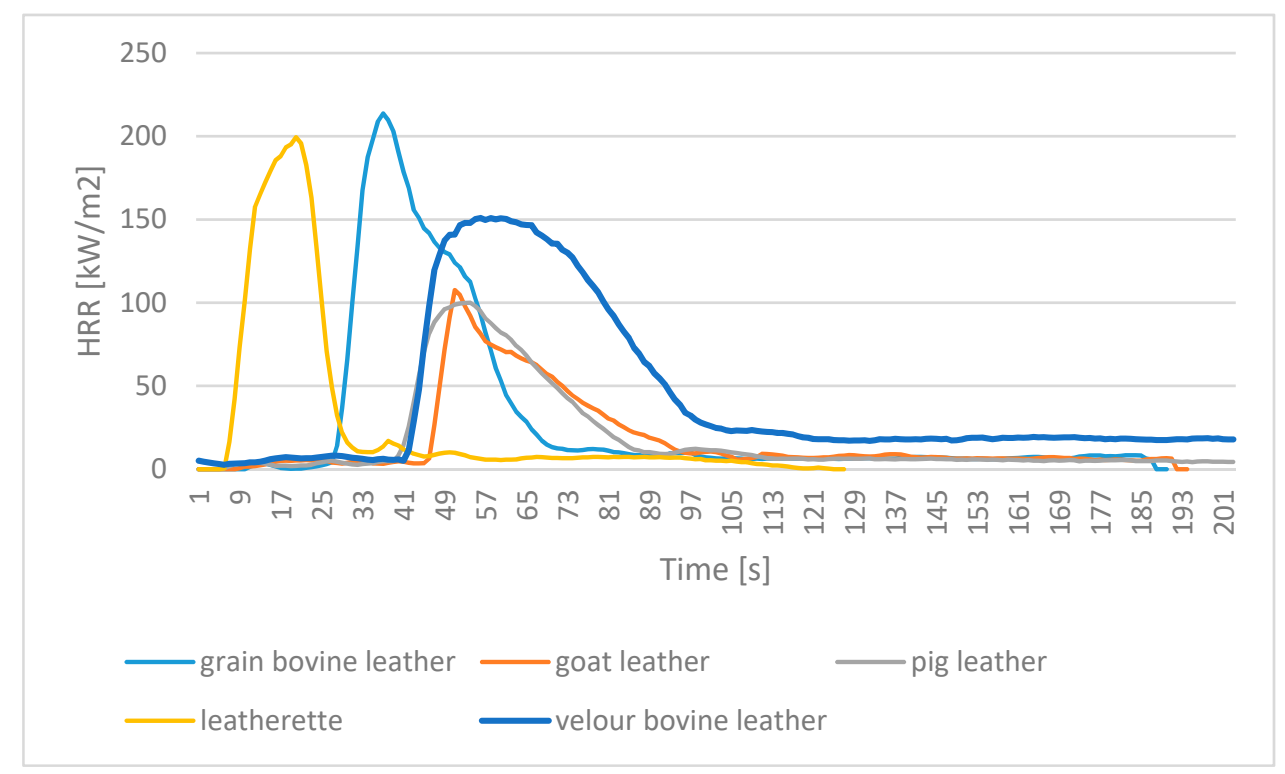

Figure 1. Dependence of heat release rate (HRR) on function of time from tested leather types at thermal exposure of $30 \mathrm{~kW} / \mathrm{m}^{2}$.

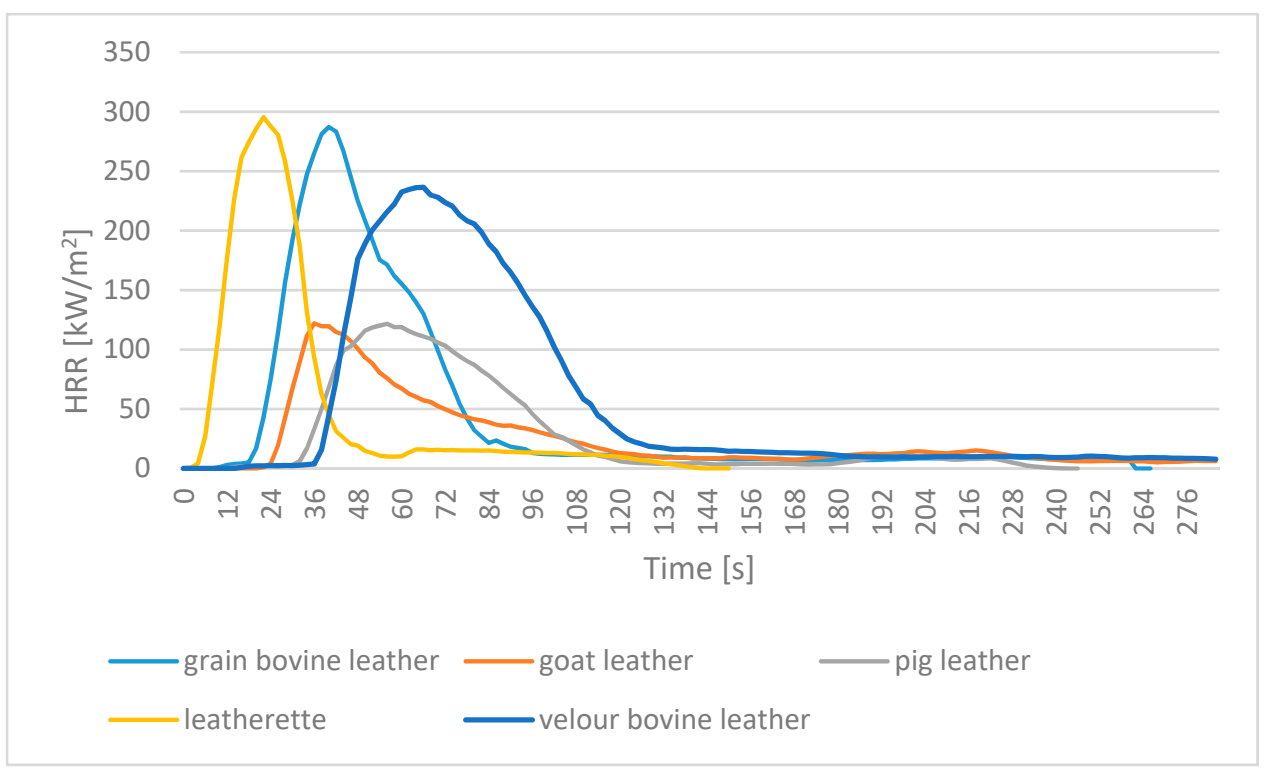

Figure 2. Dependence of HRR on function of time from tested leather types at thermal exposure of $50 \mathrm{~kW} / \mathrm{m}^{2}$.

Results of thermogravimetric analyses are presented in Table 4. A collective listing of thermogravimetric curves is presented in Figures 3 and 4. 


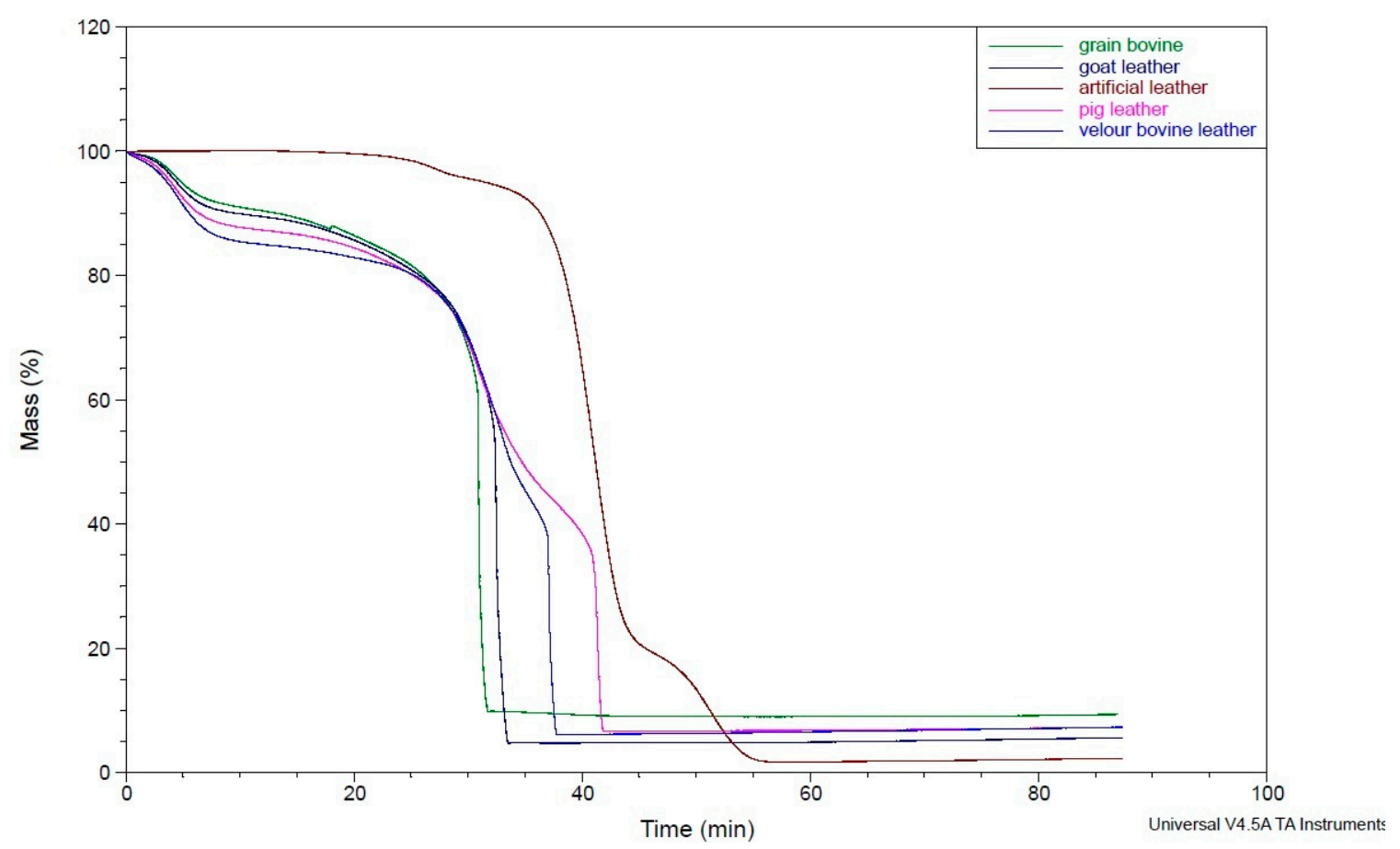

Figure 3. Thermogravimetric curves (TG) of tested leather.

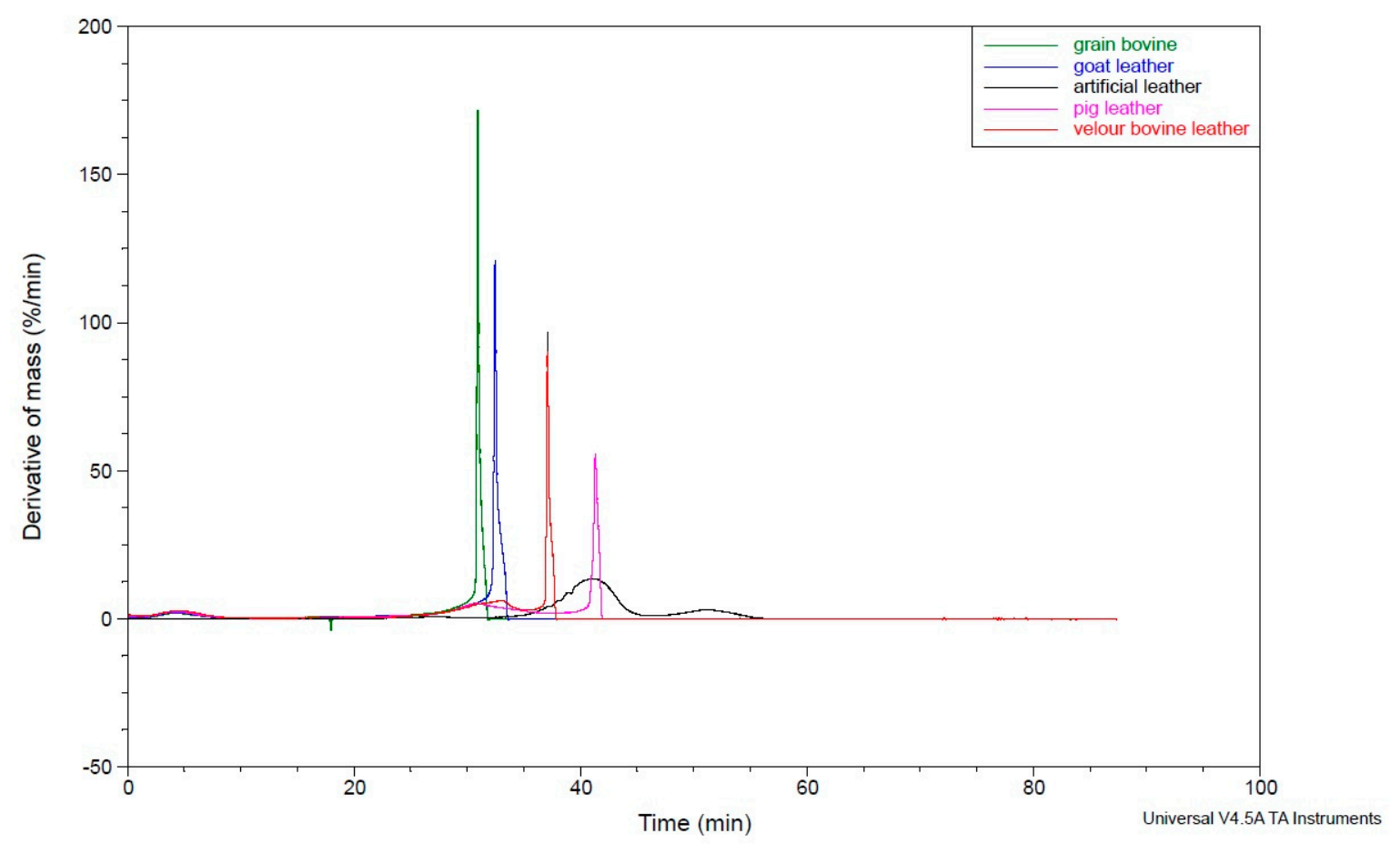

Figure 4. TG of tested leather. 
Table 4. Results of thermogravimetric analyses.

\begin{tabular}{cccccc}
\hline & \multicolumn{5}{c}{ Leather Type } \\
\hline Tested Parameters & $\begin{array}{c}\text { Grain } \\
\text { Bovine }\end{array}$ & $\begin{array}{c}\text { Goat } \\
\text { Leather }\end{array}$ & $\begin{array}{c}\text { Artificial } \\
\text { Leather }\end{array}$ & $\begin{array}{c}\text { Pig } \\
\text { Leather }\end{array}$ & $\begin{array}{c}\text { Velour Bovine } \\
\text { Leather }\end{array}$ \\
\hline $\begin{array}{c}\text { Temperature of thermal-decomposition } \\
\text { beginning }\left({ }^{\circ} \mathrm{C}\right)\end{array}$ & 282 & 271 & 323 & 277 & 281 \\
$\begin{array}{c}\text { Temperature of } 50 \% \text { mass loss }\left({ }^{\circ} \mathrm{C}\right) \\
\text { Final temperature of thermal }\end{array}$ & 320 & 340 & 418 & 356 & 343 \\
$\quad$ decomposition $\left({ }^{\circ} \mathrm{C}\right)$ & 353 & 410 & 552 & 450 & 405 \\
$\begin{array}{c}\text { Mass residue after combustion }(\%) \\
\text { Maximum mass-loss rate }(\% / \mathrm{min})\end{array}$ & 9,1 & 7.32 & 1.7 & 6.8 & 6.5 \\
$\begin{array}{c}\text { Temperature of maximum mass-loss } \\
\text { rate }\left({ }^{\circ} \mathrm{C}\right)\end{array}$ & 320 & 389 & 415 & 425 & 38.1 \\
\hline
\end{tabular}

Results obtained from testing tp determining the leather ignition temperature are presented in Table 5.

Table 5. Tested-leather ignition temperature.

\begin{tabular}{cccccc}
\hline & \multicolumn{5}{c}{ Leather Type } \\
\hline Tested Parameters & $\begin{array}{c}\text { Grain } \\
\text { Bovine }\end{array}$ & $\begin{array}{c}\text { Goat } \\
\text { Leather }\end{array}$ & $\begin{array}{c}\text { Artificial } \\
\text { Leather }\end{array}$ & $\begin{array}{c}\text { Pig } \\
\text { Leather }\end{array}$ & $\begin{array}{c}\text { Velour Bovine } \\
\text { Leather }\end{array}$ \\
\hline Ignition Temperature $\left({ }^{\circ} \mathrm{C}\right)$ & 290 & 281 & 312 & 295 & 305 \\
\hline
\end{tabular}

\section{Discussion}

A review of diagrams showing the heat-release rate in the function of ignition time for the tested leather types (Figures 1 and 2) allows us to presume that, at an external thermal radiation flux equal to $30 \mathrm{~kW} / \mathrm{m}^{2}$, the highest value for the heat-release rate was recorded for grain bovine leather. However, at thermal exposure of $50 \mathrm{~kW} / \mathrm{m}^{2}$, the highest value was recorded for leatherette. The lowest value of the heat-release rate for $30 \mathrm{~kW} / \mathrm{m}^{2}$ exposure was recorded for pig and goat leather, and for goat leather for $50 \mathrm{~kW} / \mathrm{m}^{2}$ thermal exposure. At thermal exposure of $50 \mathrm{~kW} / \mathrm{m}^{2}$ maximum HRR value for leatherette was $45 \%$ higher than the maximum HRR value for pig leather. Analysis of the value of the average heat-release rate allows the presumption that, at the studied thermal expositions, the highest average value for HRRav was recorded for the leatherette, and the lowest for the goat leather. The HRRav value for leatherette was $70 \%-80 \%$ higher compared to the HRRav value of goat leather. In the test conditions, the leatherette was found to have the shortest time until ignition and until achieving the maximum heat-release rate, while the biggest susceptibility to ignition was recorded for goat leather at $30 \mathrm{~kW} / \mathrm{m}^{2}$ and for velour bovine leather at $50 \mathrm{~kW} / \mathrm{m}^{2}$.

On the basis of the maximum amount of released carbon monoxide and dioxide from the mass of samples subjected to testing, we may presume that the largest gas volumes were released from pig leather and velour bovine leather at $30 \mathrm{~kW} / \mathrm{m}^{2}$ radiation. The remaining leather types released similar amounts of carbon oxides at the same radiation level. During sample testing at $50 \mathrm{~kW} / \mathrm{m}^{2}$ radiation, the largest amount of this gas was released by pig leather, and the smallest amount by velour bovine leather. A review of the amount of released carbon monoxide at different values of thermal exposition shows that, in general terms, the amount of released gas is larger at the lower thermal exposition used for testing. Artificial leather melts at high temperatures, contrary to natural leathers, which, as a result of the conducted testing, tended to shrink and harden.

Taking into consideration the maximum value of smoke-emission rate, we may presume that the biggest amounts were obtained for leatherette at both thermal expositions. Grain bovine leather, goat leather, and pig leather were found to have similar values, while the smallest rate of smoke emission was obtained for pig leather. The highest value of the rate of smoke emission from this leather indicates that, in fire thermal exposure, these types of leather have the greatest impact on air-pollution changes. 
Analyzing leather ignitability from a small flame, when examining the value of ignition temperature in the gaseous phase, it was found that, from all tested leather types, the leatherette had the highest ignition temperature $\left(312{ }^{\circ} \mathrm{C}\right)$, and followed by velour leather with a temperature lower by $11{ }^{\circ} \mathrm{C}$. Confirmation of obtaining the highest inflammation temperature of the flammable-gas phase of artificial leather is also why its elemental composition has the smallest percentage of hydrogen, which means that its ignition susceptibility from a small flame was the lowest. The lowest ignition temperature was recorded for goat leather, amounting to as little as $281^{\circ} \mathrm{C}$. Most likely as a result of the decomposition of goat leather, decomposition and combustion products were released from the decomposition products, which were found in this mixture to have the lowest concentration of the lower flammability limit. Results of the determination of ignition-temperature value for pig leather and leather differed by $5{ }^{\circ} \mathrm{C}$, and were within the range of $290-295^{\circ} \mathrm{C}$. Thermogravimetric analysis showed that the beginning of thermal decomposition for all sample types, with the exception of the leatherette, proved to be quite similar and remained within the range of $272-323^{\circ} \mathrm{C}$. The leatherette was found to have the biggest value of the beginning of thermal decomposition, i.e., $323^{\circ} \mathrm{C}$. This showed that, despite undergoing the lowest decomposition at the biggest temperature established during testing, this type of leather most likely did not release any products characterized by relatively low values of the lower flammability limit in the composition of thermal decomposition and combustion products; hence, for this type of leather, the highest values of ignition temperature and a temperature of $50 \%$ mass loss were recorded. This amounted to $418{ }^{\circ} \mathrm{C}$ and was $62^{\circ} \mathrm{C}$ higher than in the case of pig leather, which had the second highest value. The difference in temperatures between the remaining leather types amounted to $23^{\circ} \mathrm{C}$.

The highest remnant percentage after thermal decomposition was obtained for bovine leather, amounting to $9 \%$. This implies that this type of leather generated the least gaseous phase during its thermal decomposition in the testing conditions. The lowest remnant percentage was recorded for the leatherette $(1.7 \%)$. The difference between the remaining samples was insignificant and was within the range of $6.5 \%$ to $7.32 \%$. The quickest mass loss was recorded for bovine leather, which amounted to $174 \% / \mathrm{min}$. The lowest value was recorded for the leatherette, which only amounted to $13.4 \% / \mathrm{min}$. Bovine and velour bovine leather types were found to have temperatures of the beginning of thermal decomposition that were almost identical (the difference amounted to exactly $1^{\circ} \mathrm{C}$ ). The difference between the percentage mass residue amounted to $2.5 \%$. More material was found to have been combusted in the case of velour leather. The obtained diversified results may suggest that the velour tanning of bovine leathers facilitates the combustion of a larger amount of material. In the case of temperature analysis of the beginning of thermal decomposition, the tanning of bovine leathers was of no importance. As a result of the velour tanning of bovine leathers, this type of leather proved to be the safest product with regard to fire safety. The results recorded for those types of leather significantly diverged. The tested velour bovine leather had the highest piloted-ignition value, which means that its susceptibility to ignition was the lowest in the tested conditions. Considering the HRRmax values of the tested materials in the analyzed thermal exposures, it can be seen that they were similar to the HRRmax of wood or wood-based materials, or some polyurethane foams, but they were definitely lower than the HRRmax of, for example, non-flame-retardant epoxy materials [31-35].

\section{Conclusions}

Given the results and analysis of all the conducted leather tests, the following conclusions may be drawn:

- The highest HRRmax value was obtained during leatherette combustion at thermal exposition equal to $50 \mathrm{~kW} / \mathrm{m}^{2}$. This shows that, compared to the remaining leather types, this leather released the largest amount of heat in a unit of time, and consequently clearly affected fire rate and severity, particularly at thermal exposition occurring immediately prior to the flashover during fires and pollution in the atmosphere air. Those presumptions may also be confirmed by the highest levels of average heat-release rate, mass-loss rate value, and maximum smoke-emission rate value of the leatherette at thermal radiation equal to 30 and $50 \mathrm{~kW} / \mathrm{m}^{2}$ as compared to the other tested 
materials. The lowest HRRmax values were recorded during analysis of the pig leather sample at thermal exposition of $30 \mathrm{~kW} / \mathrm{m}^{2}$. This suggests that this type of leather, as compared to the remaining tested leather types, released the smallest amount of heat in a time unit and exerted the smallest impact on fire development. The highest value of smoke-emission rate from the artificial leather indicated that, in fire thermal exposure, this leather type has the greatest influence on air-pollution changes. The maximum smoke-emission rate and the specific emission of carbon oxide and dioxide from individual types of leather depend on the amount of thermal exposure (fire phase) and, at the same time, the effects on toxic-gas emissions to the atmosphere.

- A possible cause for the differences in the obtained leather-analysis results is the percentage of certain components and the chemical composition of leather. The largest amount of carbon was found in the leatherette, as it contains a lot of polymer additives. Consequently, the results of the conducted tests significantly diverged from the remaining leather types: the tested leatherette was found to have the largest rate of heat and smoke generation, and the biggest temperature of thermal-decomposition commencement, but at the same time the highest ignition temperature, because it contained the smallest amount of hydrogen.

- The highest flammability from a small flame was recorded for the goat leather, because this type of leather had the lowest ignition temperature, which may imply that, during thermal decomposition, this leather generated products with low values of a lower flammability limit, which relatively quickly ignited from a small flame.

Funding: This research received no external funding.

Conflicts of Interest: The authors declare no conflict of interest.

\section{References and Notes}

1. Bacardit, A.; Borràs, M.D.; Soler, J.; Herrero, V.; Jorge, J.; Olle, L.L. Behavior of leather as a protective heat barrier and fire resistant material. J. Am. Leather Chem. Assoc. 2010, 105, 51-61.

2. Zhuang, L.H.; Wang, G.W. Discussion on leather flame retarding treatment and techniques. Leather Sci. Eng. 2005, 15, 30 .

3. Półka, M.; Konecki, M.; Polakovič, P. Analysis of the range of visibility in smoke from combustion of some polymeric materials. Przemyst Chem. 2011, 90, 1567-1573.

4. Półka, M.; Kukfisz, B.; Auguścik, M.; Leszczyńska, M.; Ryszkowska, J. Impact of flame retardants on the smoke generating properties of flexible and semi-rigid polyurethane foams. Przemyst Chem. 2017, 96, 1472-1476. [CrossRef]

5. Półka, M.; Kukfisz, B.; Kulik, A. Analysis of the influence zinc stannates and keratin powder on the flammability properties epoxy material. Polimery 2017, 62, 764-771. [CrossRef]

6. Chen, W.; Liu, C.; Gong, Y.; Huang, Z. Influence of tanning on the flammability of leather. J. Soc. Leather Technol. Chem. 2007, 91, 159-161.

7. Gong, Y.; Chen, W.; Chen, J.; Gu, H. Influence of finishing on the flammability of leather. J. Soc. Leather Technol. Chem. 2007, 91, 208-211.

8. Huang, Z.; Lixin, L.I.; Chen, W.; Gui, H. Influence of fatliquoring on flammability of leather. J. Soc. Leather Technol. Chem. 2006, 90, 155-158.

9. Huang, Z.; Li, L.; Wang, Y.; Lin, Y.; Chen, W. Performance of flame retardants on leather. J. Soc. Leather Technol. Chem. 2005, 89, 225-231.

10. Zhang, X.; Chen, Y.; Fan, H.; Shi, B. Waterborne polyurethane/O-MMT nanocomposites for flame retardant leather finishing. J. Soc. Leather Technol. Chem. 2010, 94, 77-83.

11. Jiang, Y.; Li, J.; Li, B.; Liu, H.; Li, Z.; Li, L. Study on a novel multifunctional nanocomposite as flame retardant of leather. Polym. Degrad. Stab. 2015, 115, 110-116. [CrossRef]

12. Liutao, Y.; Lixin, L.; Wuyong, C.; Lin, L.; Feng, C. Thermal degradation kinetics and flame retardance of hide treated with montmorillonite-amino resin nano-composite. J. Soc. Leather Technol. Chem. 2010, 94, 9-14.

13. Mohamed, O.A.; Abdel-Mohdy, F.A. Preparation of flame-retardant leather pre-treated with pyrovatex CP. J. Appl. Polym. Sci. 2006, 99, 2039-2043. [CrossRef] 
14. Huijiao, L.; Jinwei, Y.; Ling, X.; Minglian, L.; Lixin, L. The synthesis and application of a high performance amino resin nanocomposite as leather flame retardant. J. Soc. Leather Technol. Chem. 2012, 9, 5-10.

15. Tang, Y.; Ma, X.; Lai, Z.; Fan, Y. Thermogravimetric analyses of co-combustion of plastic, rubber, leather in N2/O2 and CO2/O2 atmosphere. Energy 2015, 90, 1066-1074. [CrossRef]

16. Wei, Y.; Deng, C.; Zhao, Z.; Wang, Y. A novel organic-inorganic hybrid SiO2@DPP for the fire retardance of polycarbonate. Polym. Degrad. Stab. 2018, 154, 177-185. [CrossRef]

17. Śmiechowski, K. The Influence of the Addition of Melamine and Silica in the Retanning of Leather on the Flammability and other Selected Properties of Leather. Saf. Fire Tech. 2018, 51, 70-83. [CrossRef]

18. Alptekin, E.; Canakci, M.; Sanli, H. Evaluation of leather industry wastes as a feedstock for biodiesel production. Fuel 2012, 95, 214-220. [CrossRef]

19. Altun, S.; Yasşar, F. Biodiesel production from leather industry wastes as an alternative feedstock and its use in diesel engines. Energy Explor. Exploit. 2013, 31, 759-770. [CrossRef]

20. Fela, K.; Wieczorek-Ciurowa, K.; Konopka, M.; Wozny, Z. Present and prospective leather industry waste disposal. Pol. J. Chem. Technol. 2011, 13, 53-55. [CrossRef]

21. Dixit, S.; Yadav, A.; Dwivedi, P.D.; Das, M. Toxic hazards of leather industry and technologies to combat threat: A review. J. Clean. Prod. 2015, 87, 39-49. [CrossRef]

22. Aquima, P.; Hansena, E.; Gutterresb, M. Water reuse: An alternative to minimize the environmental impact on the leather industry. J. Environ. Manag. 2019, 230, 456-463. [CrossRef] [PubMed]

23. Hu, J.; Xiao, Z.; Zhou, R.; Deng, W.; Wang, M.; Ma, S. Ecological utilization leather tannery waste with circular economy model. J. Clean. Prod. 2011, 19, 221-228. [CrossRef]

24. Gil, R.R.; Girón, R.P.; Lozano, M.S.; Ruiz, B.; Fuente, E. Pyrolysis of biocollagenic wastes of vegetable tanning. Optimization and kinetic study. J. Anal. Appl. Pyrolysis 2012, 98, 129-136. [CrossRef]

25. ISO 5660:2015. Reaction to fire test-Heat release, smoke production and mass loss rate, Part 1: Rate of heat release from building products, Part 2: Smoke production rate (dynamic measurement)-Cone calorimetric method.

26. Polish Standard PN-69/C-89022:1969, Plastics: Determination of ignition temperature.

27. Standard EN ISO 11358:2014, Plastics. Thermogravimetry (TG) of polymers. General rules.

28. Konecki, M. Influence of heat release rate and smoke emission on fire development in room layout, Habilitation dissertation, SGSP Edition, Warsaw. 2007.

29. Brohez, S. Uncertainty analysis oh heat release rate measurement from oxygen consumption calorimetry. Fire Mater. 2005, 29, 1-13. [CrossRef]

30. Sychta, K. Comparative Analysis of the Heat Emission Intensity of Marine Materials and a Method to Improve Measurement Accuracy. Ph.D. Thesis, Szczecin University of Technology, Szczecin, Poland, 2006.

31. Mizera, K.; Kirpluks, M.; Cabulis, U.; Leszczyńska, M.; Półka, M.; Ryszkowska, J. Characterisation of ureaurethane elastomers containing tall oil-based polyols. Ind. Crop. Prod. 2018, 113, 98-110. [CrossRef]

32. Ryszkowska, J.; Leszczyńska, M.; Auguścik, M.; Bryśkiewicz, A.; Półka, M.; Kukfisz, B.; Wierzbicki, Ł.; Aleksandrowicz, J.; Szczepkowski, L.; Oliwa, R. Cores of composite structures made of semi-rigid foams for use as protecting shields for firefighters. Polimery 2018, 63, 125-133. [CrossRef]

33. Półka, M. Analysis of heat and smoke release rate from unmodified and flame retardant epoxy materials. Polimery 2011, 10, 734-742.

34. Gałaj, J.; Półka, M.; Wnęk, W. Effect of addition of fire retardants on some fire properties of epoxy materials). Przemyst Chem. 2012, 91, 1378-1384.

35. Półka, M.; Ziembaczewski, E. A comparative study on some thermal kinetic parameters of Laminated Veneer Lumber (LVL). Ann. Wars. Univ. Life Sci. SGGW Wood Technol. 2008, 64, 205-208.

(C) 2019 by the author. Licensee MDPI, Basel, Switzerland. This article is an open access article distributed under the terms and conditions of the Creative Commons Attribution (CC BY) license (http://creativecommons.org/licenses/by/4.0/). 